\title{
Australian Journal of

\section{Chemical properties of the soil fertilized with potassium and calcium in guava cultivation cv. 'Paluma'}

\section{Alian Cássio Pereira Cavalcante ${ }^{1 *}$, Lourival Ferreira Cavalcante ${ }^{2}$, Adailza Guilherme Cavalcante ${ }^{3}$ Antonio Michael Pereira Bertino ${ }^{4}$, Antonio Missiemario Pereira Bertino ${ }^{5}$, Nubia Marisa Ferreira ${ }^{6}$}

${ }^{1}$ Universidade Federal de Viçosa, Viçosa, Minas Gerais, Brasil

${ }^{2}$ Universidade Federal da Paraíba, Areia, Paraíba, Brasil

${ }^{3}$ Universidade Estadual Paulista - FCAV/UNESP. Jaboticabal, São Paulo, Brasil

${ }^{4}$ Universidade Estadual Paulista - FCAV/UNESP. Jaboticabal, São Paulo, Brasil

${ }^{5}$ Universidade Federal da Paraíba, Areia, Paraíba, Brasil

${ }^{6}$ Universidade Federal Rural do Semi-Árido, Mossoró, Rio Grande do Norte, Brazil

*Corresponding author: cassio.alian216@gmail.com

\begin{abstract}
Soil fertility gradually declines over time and under continuous cultivation. It negatively reflects on the yield and quality of crop production, including guava, which is a perennial fruit of high economic potential. Therefore, the objective of this study is to evaluate the effect of potassium doses with and without the application of calcium in soil cultivated with guava "Paluma." The experimental design was a randomized block with factorial arrangement of $2 \times 5$, relative to the soil with and without $120 \mathrm{~g} \mathrm{plant}^{-1}$ year $^{-1}$ calcium (using calcium nitrate) and five doses of $\mathrm{K}_{2} \mathrm{O}$ from $0,45,90,135$, and $180 \mathrm{~g} \mathrm{plant}^{-1}$ year $^{-1}$ in the form of potassium chloride. The variables analyzed in soil were potential hydrogen, organic matter, phosphorus, potassium, calcium, magnesium, sodium, sum of bases, hydrogen plus aluminum, aluminum, cation exchange capacity, and soil base saturation. The soil fertility was higher in the treatments with potassium (K) fertilizer which has recommended doses between 90 and $135 \mathrm{~g} \mathrm{plant}^{-1}$ year $^{-1}$ without application of calcium in the soil.
\end{abstract}

Keywords: frit, fertilization, soil fertility, Psidium guajava, soil.

\section{Introduction}

Soil fertility gradually decreases with intensive harvesting and reduces the availability of soil nutrients to plants. The continuous cultivation of plants increases the nutrient variation in the soil, which can cause a nutritional imbalance, and to maintain the high fertility of the soil, the application of fertilizers in the agricultural soils is necessary (Fida et al., 2011). The intensive use of the soil in perennial crops without the replacement of nutrients decreases the availability of nutrients and, consequently, losses crop productivity. Therefore, soil fertility monitoring is a decisive activity for the fertilization schedule as a goal to improve the components of soil fertility, crop nutrition, and in effect, yield and quality of production (Souza et al. 2014).

Continuous cultivation of plants in the same area over time provides low soil fertility because of continuous cultivation, making fertilization necessary to increase the growth and yield of perennial fruit crops. In this way, research has sought information on the sources, concentrations, and the best way of applying nutrients and response in fruit production (Silva et al., 2001; França et al., 2017).
The perennial plants, such as fruit, spend a large period using almost the same volume of soil, so great attention should be paid to the rhizosphere of plants, especially nutrient availability in the soil solution (Natale et al., 2012). Specifically in guava, the need for fertilization to raise productivity and maintain orchard sustainability becomes a constant need (Kumar et al., 2014). These soil conditions determine the development of the plant root system, which is directly associated with plant growth and nutrition (Montes et al., 2016a). The high mobility of nutrients into the soil, such as $\mathrm{K}$ can be strongly influenced by changes in management and fertilization of culture (Moges et al., 2013). This stimulates the best nutrient regulation for the photosynthetic processes of plants (Jin et al., 2011). Calcium (Ca) is also a nutrient important for the physiological growth and development of plants and has a key role in improving the structure of the cell wall of the plant and fruit in addition to root growth stimulator (Karley; White, 2009; Balic et al., 2014), besides current as a second messenger in plant physiology (Edel et al., 2017). Considering the importance of 
soil fertility and the interaction between $\mathrm{K}$ and $\mathrm{Ca}$ in the soil, the objective of this research was to evaluate the effect of $K$ doses with and without $\mathrm{Ca}$ application in the soil, cultivated with "Paluma" guava plants.

\section{Results and discussion}

Fertilization with $\mathrm{K}$ in the soil without $\mathrm{Ca}$ did not influence the $\mathrm{pH}$ (Figure 1A). The behavior of the data is in agreement with Montes et al. (2016b) when they concluded that soil cultivated with "Paluma" guava only fertilized with $\mathrm{K}$ did not change $\mathrm{pH}$. On the other hand, the $\mathrm{pH}$ of the soil increased linearly with the $\mathrm{K}_{2} \mathrm{O}$ doses in the treatments with $\mathrm{Ca}$, this increase according to Wang et al. (2012) is a response of the action of $\mathrm{Ca}$ and $\mathrm{K}$ on $\mathrm{pH}$ rise because the respective nutrients act in the exchange complex raising the sum of exchangeable bases and, in effect, the $\mathrm{pH}$ reducing the acidity of the soil that was 5.53 before the treatments were applied to the soil.

The organic matter content in the soil increased from 11.35 to $12.41 \mathrm{~g} \mathrm{~kg}^{-1}$, representing a $9.3 \%$ increase between the treatments without and with calcium nitrate (Figure 1B). Despite the increase between the treatments with and without $\mathrm{Ca}^{2+}$ and the mineralization of the mulch plant material, in the crown area in all plants, the data are lower than the initial average value of $13.1 \mathrm{~g} \mathrm{dm}^{-3}$ of the soil (Table 1 ) before the application of the treatments.

The increase in relation to the treatments without and with $\mathrm{Ca}$ is in agreement with Feng et al. (2016) when concluding that $\mathrm{Ca}$ increases the rate of microbial respiration and consequently accelerates the degradation of crop residues, resulting in a higher content of organic matter in the soil. $\mathrm{Ca}$, as a conditioning agent of physical properties, contributes to the sustainability of the agroecosystem with positive effects on the organic matter content and the stimulus to microbial activity and soil nutrient cycling processes (Balaria et al., 2015), in addition to promoting a greater root development reflecting in the increment of organic matter in the soil.

Phosphorus ( $P$ ) content (Figure 2A) increased significantly compared with the soil before application of the treatments (Table 1), going from low $\left(9.7 \mathrm{mg} \mathrm{kg}^{-1}\right)$ to excessively high, up to $160 \mathrm{mg} \mathrm{kg}^{-1}$. Soil-free Ca data did not fit any type of regression and were represented by the mean value of $132.76 \mathrm{mg} \mathrm{kg}^{-1}$. In the soil with $\mathrm{Ca}$, initially, the contents decreased from 159.6 to $123.4 \mathrm{mg} \mathrm{kg}^{-1}$ at the lowest estimated dose of $85 \mathrm{~g} \mathrm{plant}^{-1}$ year ${ }^{-1}$ of $\mathrm{K}_{2} \mathrm{O}$; however, from that dose, the increase of $\mathrm{K}$ increased the concentration of soil $\mathrm{P}$, a similar situation was recorded by Nascente and Cobucci (2015), when they reported that fertilization with $\mathrm{Ca}$ may provide greater $P$ availability in the soil because of the synergism between the two nutrients. The increase in $\mathrm{P}$ may also be related to the increase of organic matter in the soil. The increase of $K$ contents in the soil is a response to the fertilization with potassium chloride, but higher values of $\mathrm{K}$ in the soil without addition of $\mathrm{Ca}$ are observed (Figure 2B). The lower soil concentration with $\mathrm{Ca}$, according to Amini et al. (2012) is a function of the antagonistic action between $\mathrm{K}$ and $\mathrm{Ca}$, contributing to the reduction of $\mathrm{K}$ in the soil with $\mathrm{Ca}$.
The availability of $\mathrm{K}$ can be influenced by internal or external factors, such as the concentration in the medium and external as a stimulus or inhibition to the assimilation by plants (Lalitha and Dhakshinamoorthy, 2015). Therefore, the monitoring of soil fertility in guava orchards should be a systematic practice, especially with respect to the $K$, which among the macronutrients is the most exported with the fruit harvest (Souza et al., 2014). Considering that the soil before the installation of the experiment was with $\mathrm{K}$ values below that required by the guava tree can explain the behavior of both treatments with increasing linear response. The increase of the $\mathrm{K}_{2} \mathrm{O}$ doses linearly increased the levels of $\mathrm{Ca}$ in the soil, at $0.006 \mathrm{cmol}_{\mathrm{c}} \mathrm{dm}^{-3}$ level per unit increase of $\mathrm{K}_{2} \mathrm{O}$, in the treatments without calcium nitrate (Figure $2 \mathrm{C}$ ). In the present study, the presence of $\mathrm{Ca}^{2+}$ in the soil solution was observed in the presence of a high concentration of $\mathrm{K}$ in the root environment as shown by (Amini et al., 2012; Montes et al. 2016a).

As for the soil with calcium nitrate, it is possible to observe a reduction in the availability of $\mathrm{Ca}^{2+}$ in the minimum estimated dose of $\mathrm{K}_{2} \mathrm{O}$ of $83 \mathrm{~g} \mathrm{plant}^{-1}$ year $^{-1}$, but increasing as a result of the increase of $\mathrm{K}_{2} \mathrm{O}$ in the form of potassium chloride. The initial reduction is compatible with the literature by the competitive inhibition between $\mathrm{K}$ and $\mathrm{Ca}$ from the minimum dose, as well as in the soil without calcium nitrate, which contradicts the literature (Marques et al., 2011).

Ca content in the soil without Ca decreased from 2.17 to $1.26 \mathrm{cmol}_{\mathrm{c}} \mathrm{dm}^{-3}$ among treatments with and without the minimum estimated dose of $95 \mathrm{~g} \mathrm{plant}^{-1}$ year $^{-1} \mathrm{~K}_{2} \mathrm{O}$, but were increased with the addition of $\mathrm{K}_{2} \mathrm{O}$ above the estimated minimum dose (Figure 2D). This decline is, in part, in agreement with the literature because of the high concentrations of $\mathrm{K}$ reducing the availability of magnesium $(\mathrm{Mg})$ by the antagonistic action between $\mathrm{K}^{+}$and $\mathrm{Mg}^{2+}$ and causing imbalance in soil fertility (Amini et al., 2012). Mg data, in the soil with calcium nitrate, did not fit any mathematical model because of the increase of the $K$ doses, corresponding to the value of $1.25 \mathrm{cmol}_{\mathrm{c}} \mathrm{dm}^{-3}$.

For Parent et al. (2012) and Montes et al. (2016a), the increase of $\mathrm{K}$ and $\mathrm{Ca}$ concentration in the soil can cause a decrease in the availability of $\mathrm{Mg}$ in response to the antagonistic competition between $\mathrm{K}$ and $\mathrm{Ca}$ with $\mathrm{Mg}$ (Marques et al., 2011). The nutrient increase in the soil may be due to the addition of $30 \mathrm{~g} \mathrm{plant}^{-1}$ of $\mathrm{Mg}$ sulphate covering the first fertilization with nitrogen, phosphorus and potassium (NPK) of the plants after the experiment was started and the participation of the element by the mineralization of the vegetal material of the mulch in the area of crown projection of all plants (Table 1 ).

The sum of exchangeable bases of the soil without calcium nitrate was initially reduced from 3.7 to $3.6 \mathrm{cmol}_{c} \mathrm{dm}^{-3}$ between the treatments with and without the estimated minimum dose of $41 \mathrm{~g}$ plant $^{-1}$ year $^{-1}$ of $\mathrm{K}_{2} \mathrm{O}$ and increased, from this dose, to $3.588,3.727,4.110$, and $4.735 \mathrm{cmol}_{\mathrm{c} \mathrm{dm}} \mathrm{cm}^{-3}$ with the addition of 45,90, 135 and $180 \mathrm{~g} \mathrm{plant}^{-1}$ year $^{-1}$ of $\mathrm{K}_{2} \mathrm{O}$ to the soil, with an average value of $3.91 \mathrm{cmol}_{\mathrm{c}} \mathrm{dm}^{-3}$ (Figure $3 \mathrm{~A}$ ). In the soil with calcium nitrate, according to $\mathrm{K}_{2} \mathrm{O}$ doses, the data did not fit any regression model and corresponded to the mean value of $3.80 \mathrm{cmol}_{\mathrm{c}} \mathrm{dm}^{-3}$. 
Table 1. Chemical and physical attributes of the soil in $0-40 \mathrm{~cm}$ layer, before installation of the experiment and chemical composition of the vegetation cover before installation of the experiment and end of production.

\begin{tabular}{|c|c|c|c|c|c|c|}
\hline \multirow[t]{2}{*}{ Chemical atributes } & \multirow[t]{2}{*}{ Value } & \multirow[t]{2}{*}{ Physical atributes } & \multirow[t]{2}{*}{ Value } & \multicolumn{3}{|c|}{$\begin{array}{l}\text { Chemical composition of the } \\
\text { vegetal cover }\end{array}$} \\
\hline & & & & & Before & After \\
\hline $\mathrm{pH}\left(\mathrm{H}_{2} \mathrm{O}\right)$ & 5.53 & Thick sand $\left(\mathrm{g} \mathrm{kg}^{-1}\right)$ & 544 & $\mathrm{~N}\left(\mathrm{~g} \mathrm{~kg}^{-1}\right)$ & 11.9 & 18.0 \\
\hline$P\left(\mathrm{mg} \mathrm{dm}^{-3}\right)$ & 9.7 & Fine sand $\left(\mathrm{g} \mathrm{kg}^{-1}\right)$ & 283 & $P\left(g ~ k g^{-1}\right)$ & 2.5 & 1.7 \\
\hline $\mathrm{K}^{+}\left(\mathrm{cmol}_{\mathrm{c}} \mathrm{dm}^{-3}\right)$ & 0.13 & silt $\left(\mathrm{g} \mathrm{kg}^{-1}\right)$ & 91.0 & $K\left(\mathrm{~g} \mathrm{~kg}^{-1}\right)$ & 11.9 & 3.3 \\
\hline $\mathrm{Ca}^{2+}\left(\mathrm{cmol}_{\mathrm{c}} \mathrm{dm}^{-3}\right)$ & 1.79 & clay $\left(\mathrm{g} \mathrm{kg}^{-1}\right)$ & 83.0 & $\mathrm{Ca}\left(\mathrm{g} \mathrm{kg}^{-1}\right)$ & 4.6 & 12.9 \\
\hline $\mathrm{Mg}^{2+}\left(\mathrm{cmol}_{\mathrm{c}} \mathrm{dm}^{-3}\right)$ & 0.48 & dispersed clay $\left(\mathrm{g} \mathrm{kg}^{-1}\right)$ & 19.0 & $\mathrm{Mg}\left(\mathrm{g} \mathrm{kg}^{-1}\right)$ & 2.8 & 2.6 \\
\hline $\mathrm{Na}^{+}\left(\mathrm{cmol}_{\mathrm{c}} \mathrm{dm}^{-3}\right)^{\prime}$ & 0.010 & Degree of flocculation (\%) & 77.2 & $\mathrm{~S}\left(\mathrm{~g} \mathrm{~kg}^{-1}\right)$ & 2.0 & 1.6 \\
\hline $\mathrm{SB}\left(\mathrm{cmol}_{\mathrm{c}} \mathrm{dm}^{-3}\right)$ & 2.41 & Dispersion index (\%) & 28.2 & $\mathrm{Cu}\left(\mathrm{mg} \mathrm{kg}^{-1}\right)$ & 7.20 & 9.2 \\
\hline $\mathrm{H}^{+}+\mathrm{Al}^{3+}\left(\mathrm{cmol}_{\mathrm{c}} \mathrm{dm}^{-3}\right)$ & 1.85 & Soil density $\left(\mathrm{g} \mathrm{cm}^{-3}\right)$ & 1.58 & $\mathrm{Fe}\left(\mathrm{mg} \mathrm{kg}^{-1}\right)$ & 149.8 & 1705.5 \\
\hline $\mathrm{Al}^{3+}\left(\mathrm{cmol}_{\mathrm{c}} \mathrm{dm}^{-3}\right)$ & 0.0 & Particle density $\left(\mathrm{g} \mathrm{cm}^{-3}\right)$ & 2.64 & $\mathrm{Zn}\left(\mathrm{mg} \mathrm{kg}^{-1}\right)$ & 55.20 & 144.5 \\
\hline $\operatorname{CTC}\left(\mathrm{cmol}_{\mathrm{C}} \mathrm{dm}^{-3}\right)$ & 4,26 & Total porosity $\left(\mathrm{m}^{3} \mathrm{~m}^{-3}\right)$ & 0.40 & $\mathrm{Mn}\left(\mathrm{mg} \mathrm{kg}^{-1}\right)$ & 47.80 & 124.3 \\
\hline V (\%) & 56.3 & Micro porosity (\%) & 16.3 & $\mathrm{~B}\left(\mathrm{mg} \mathrm{kg}^{-1}\right)$ & 25.46 & 20.2 \\
\hline $\begin{array}{l}\text { Organic matter } \\
\left(\mathrm{g} \mathrm{kg}^{-1}\right)\end{array}$ & 13.1 & Macro porosity (\%) & 83.7 & & & \\
\hline $\mathrm{S}\left(\mathrm{mg} \mathrm{dm} \mathrm{m}^{-3}\right)$ & 7.20 & humidity - $0.010 \mathrm{MPa}\left(\mathrm{g} \mathrm{kg}^{-1}\right)$ & 64.8 & & & \\
\hline$B\left(\mathrm{mg} \mathrm{dm}^{-3}\right)$ & 0.19 & humidity - $0.033 \mathrm{MPa}\left(\mathrm{g} \mathrm{kg}^{-1}\right)$ & 48.0 & & & \\
\hline $\mathrm{Cu}\left(\mathrm{mg} \mathrm{dm}^{-3}\right)$ & 0.80 & humidity - $1.500 \mathrm{MPa}\left(\mathrm{g} \mathrm{kg}^{-1}\right)$ & 25.1 & & & \\
\hline $\mathrm{Mn}\left(\mathrm{mg} \mathrm{dm}^{-3}\right)$ & 7.40 & water available $\left(\mathrm{g} \mathrm{kg}^{-1}\right)$ & 39.8 & & & \\
\hline $\left.\mathrm{Fe}(\mathrm{mg} \mathrm{dm})^{-3}\right)$ & 54 & & & & & \\
\hline $\mathrm{Zn}\left(\mathrm{mg} \mathrm{dm}^{-3}\right)$ & 1.84 & & & & & \\
\hline
\end{tabular}
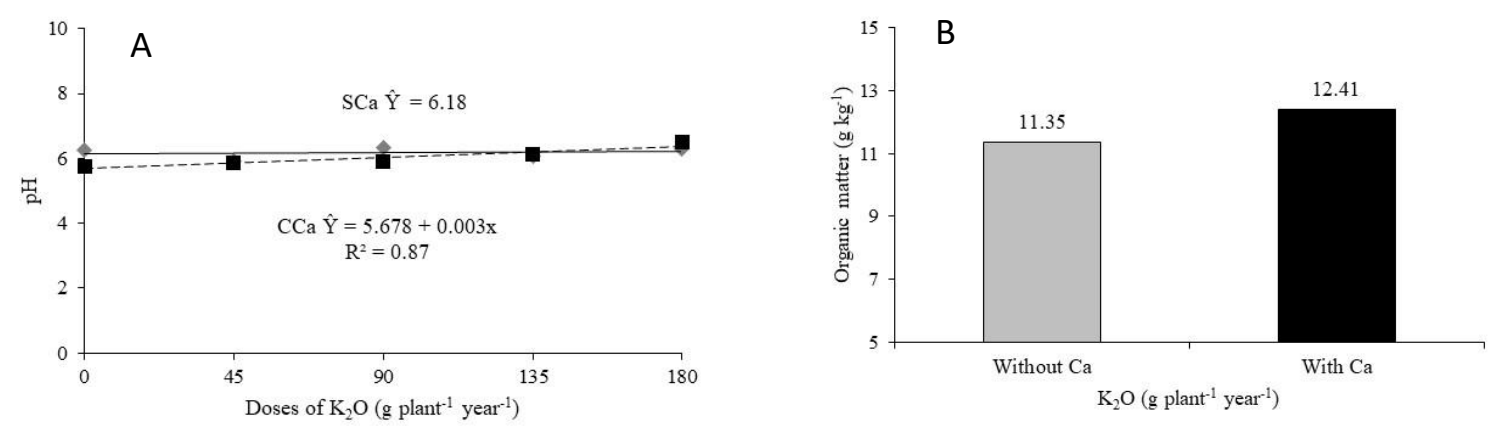

Fig 1. $\mathrm{pH}$ - Hydrogen ionic potential of soil (1A), and Soil organic matter content (1B), cultivated with 'Paluma' guava, as a function of $\mathrm{K}$ doses, in the soil without $\mathrm{Ca}(\ldots)$ and with $\mathrm{Ca}(--)$.
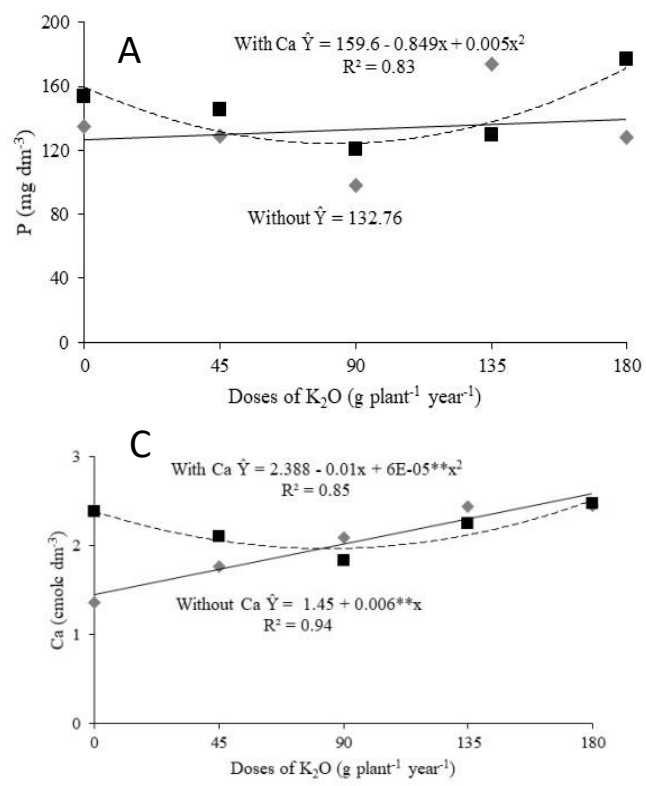
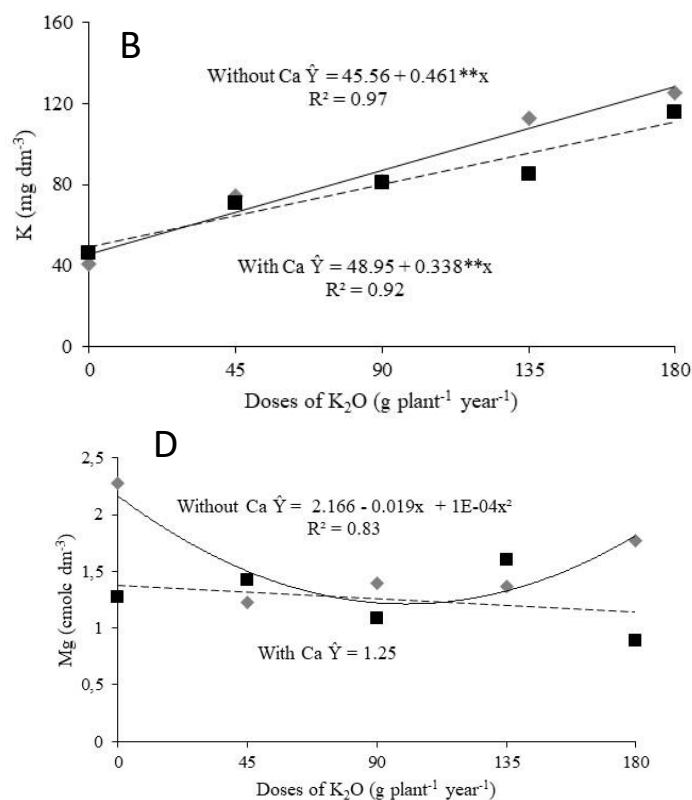

Fig 2. $\mathrm{P}$ - $\mathrm{P}$ content in soil (2A), $\mathrm{K}$ content in soil (2B), $\mathrm{Ca}$ - Ca content in soil (2C) and Mg content in soil (2D) cultivated with 'Paluma' guava, as a function of $\mathrm{K}$ doses, in the soil without $\mathrm{Ca}(\ldots)$ and with $\mathrm{Ca}(---)$. 

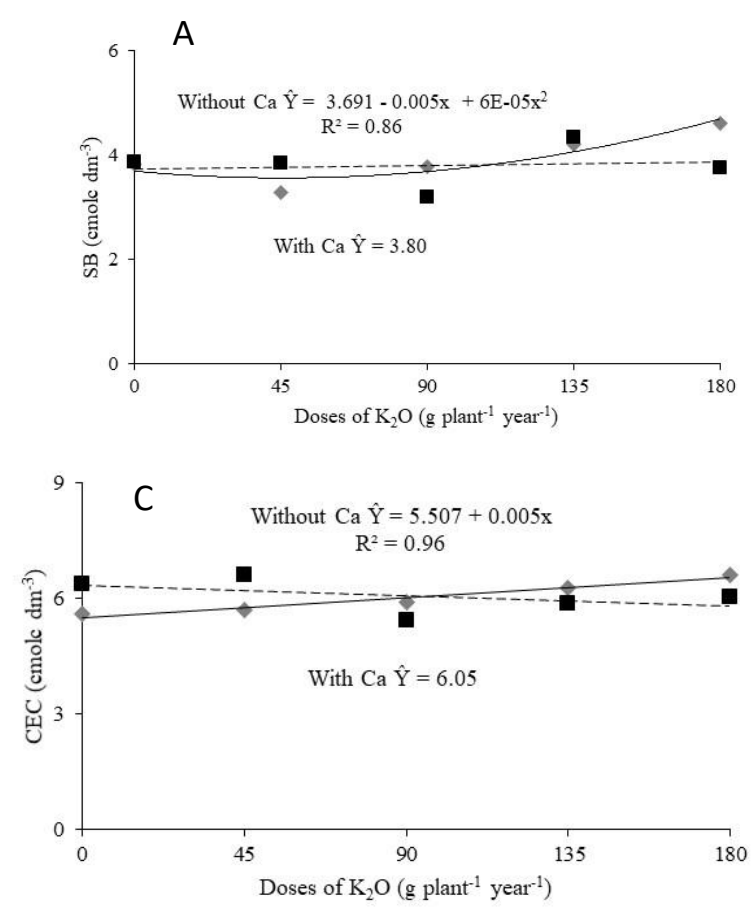

B
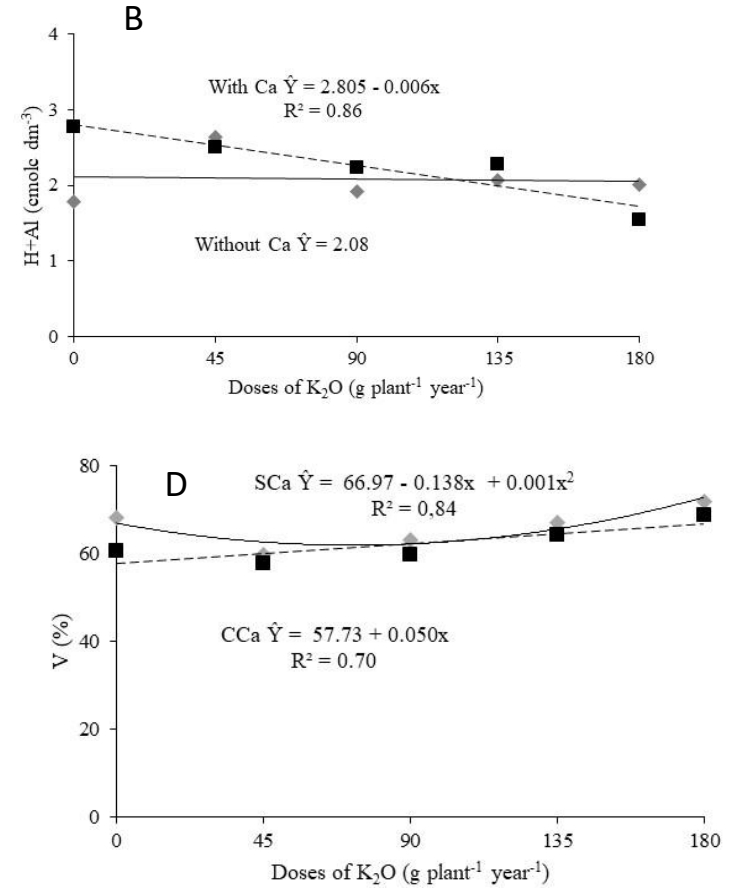

Fig 3. SB - Sum of bases in soil ( $3 \mathrm{~A}), \mathrm{H}+\mathrm{Al}$ - Potential soil acidity (3B), cation exchange capacity (CEC) in soil (3C) and saturation (V) by exchangeable bases in the soil (3D), cultivated with "Paluma" guava, as a function of $\mathrm{K}$ doses, in the soil without Ca (__ ) and with Ca (---).

The superiority of the sum of bases in the treatments without addition of $\mathrm{Ca}$ in relation to the soil with calcium nitrate is in agreement with the contents of $\mathrm{K}$ and $\mathrm{Ca}^{2+}$ in soil $\mathrm{cmol}_{\mathrm{c}} \mathrm{dm}^{-3}$ (Figures 2B and 2C) and may be due to the effects of the interaction between $\mathrm{Ca}$ and $\mathrm{K}$ reflected in a smaller sum of exchangeable bases. The mean values of 3.91 and $3.80 \mathrm{cmol}_{\mathrm{c}} \mathrm{dm}^{-3}$ exceeded the initial content of $2.40 \mathrm{cmol}_{\mathrm{c}}$ $\mathrm{dm}^{-3}$ in $62.9 \%$ and $58.3 \%$ of the soil before application of the treatments (Table 1) as additional responses of $\mathrm{K}$ and $\mathrm{Ca}$ from the treatments, fertilization with $30 \mathrm{~g} \mathrm{plant}^{-1}$ of $\mathrm{Mg}$ sulfate, and mineralization of the plant material used in the mulching of the crown area of the plants. The increases are in agreement with Rozane et al. (2013) when they verified the increases in the sum of exchangeable bases of the soil by mineral fertilization with $\mathrm{K}$ and application of an organic byproduct of the processing of guava.

The levels of $\mathrm{H}^{+}+\mathrm{Al}^{3+}$ that express the potential acidity (Figure 3B) did not vary with the $\mathrm{K}_{2} \mathrm{O}$ doses in the soil without $\mathrm{Ca}$, and the data did not fit any mathematical model, with a mean of $2.08 \mathrm{cmol}_{\mathrm{c}} \mathrm{dm}^{-3}$ and therefore higher than the initial value of $1.85 \mathrm{cmol}_{\mathrm{c}} \mathrm{dm}^{-3}$ before application of the treatments (Table 1). This increase can be a response of the high $\mathrm{C} / \mathrm{N}$ ratio of $21: 1$ in the plant cover material in the crown area of the plants (Table 1), keeping the soil even more acidic than the initial condition. It is also noticed in the $\mathrm{Ca}$ and the hydrogen contents plus aluminum. The addition of $\mathrm{Ca}$ and $\mathrm{K}$ increased the adsorption of the respective cations and consequently reduced the negative loads of the soil, reducing the potential acidity (Cunha et al., 2012).

Increases in the sum of exchangeable bases were reflected in the elevation of the cation exchange capacity of the soil cation exchange capacity (CEC), as a function of the $\mathrm{K}_{2} \mathrm{O}$ rates. According to Figure $3 \mathrm{C}$, there is a linear increase of CTC in the soil without calcium nitrate at the level of 0.26 $\mathrm{cmol}_{\mathrm{c}} \mathrm{dm}^{-3}$ per unit increment of $\mathrm{K}_{2} \mathrm{O}$, raising the values from
5.51 to $6.41 \mathrm{cmol}_{c} \mathrm{dm}^{-3}$, which indicates a $16.3 \%$ increase between treatments with and without the highest dose of $\mathrm{K}_{2} \mathrm{O}$ in the form of potassium chloride and with an average value of $5.96 \mathrm{cmol}_{\mathrm{c}} \mathrm{dm}^{-3}$ for the soil with and without each dose of the mineral fertilizer.

As for the soil with calcium nitrate, as well as in the sum of exchangeable bases, the data did not fit any mathematical model and were evaluated by the average value of 6.05 $\mathrm{cmol}_{\mathrm{c}} \mathrm{dm}^{-3}$. When the mean values were compared with $4.25 \mathrm{cmol}_{\mathrm{c}} \mathrm{dm}^{-3}$ of the soil before starting the experiment (Table 1), increases of $40.2 \%$ and $42.3 \%$ were observed in relation to the soil before the application of the treatments. The increases are in agreement with Parent et al. (2012) after verifying that the increase of $\mathrm{K}$ raises cation contents and consequently increases the sum of bases and the cationic exchange capacity of the soil. The increase of $\mathrm{K}_{2} \mathrm{O}$ in the soil without $\mathrm{Ca}$ reduced the saturation percentage by exchangeable bases from $66.97 \%$ to $62.31 \%$ in the lowest dose of $69 \mathrm{~g} \mathrm{plant}^{-1}$ year $^{-1}$ of $\mathrm{K}_{2} \mathrm{O}$ applied to the soil. However, it can be seen that from the lowest dose, the values increased to $62.65 ; 66.57$ and 74.53 at doses of 90 , 135 and 180 g plant $^{-1}$ year $^{-1}$ of $\mathrm{K}_{2} \mathrm{O}$, resulting in an average value of $66.61 \%$ (Figure $3 D$ ). In the same figure, it is also verified, in the soil with calcium nitrate, that the values increased linearly at the level of $0.05 \%$ for each unit of $\mathrm{K}_{2} \mathrm{O}$, from $57.73 \%$ to $66.73 \%$ between the treatments without and with $180 \mathrm{~g} \mathrm{plant}^{-1}$ year $^{-1}$ of the mineral input and average value of $62.21 \%$ among all the treatments.

Despite the low variation of the average values $(66.61 \%$ and $62.21 \%$ ) between the soil without and with calcium nitrate, the addition of $\mathrm{Ca}$ and $\mathrm{K}$ as a source of variation, the incorporation of $30 \mathrm{~g} \mathrm{cova}^{-1}$ of sulfate, and the mineralization of the Brachiaria decumbens grass used in the mulch in all treatments exceeded the initial value of $57.73 \%$ 
(Table 1) in $18.31 \%$ and $10.49 \%$, respectively, and with superiority in the soil without nitrate of Ca.

The increase in saturation by exchangeable bases is associated with the increase of $\mathrm{Ca}, \mathrm{Mg}$, and $\mathrm{K}$ contents and the decrease of $\mathrm{H}^{+}+\mathrm{Al}^{3+}$ (Souza et al., 2014). As verified by the initial values and the soil, at the time of the plants in full bloom and according to Natale et al. (2007), soils with saturation by exchangeable bases above $55 \%$ express an adequate level of fertility for the guava crop.

\section{Materials and methods}

\section{Place of study and type of soil}

The experiment was developed from August 2015 to May 2016, on property, the Monkeys Site municipality of Remígio-PB, $18 \mathrm{~km}$ from the headquarters of the Center for agricultural sciences of Federal University of Paraíba. The soil of the experimental area, according to the criteria of the Brazilian System of soil Classification-SIBCS (EMBRAPA, 2013), was classified as Neossolo Regolítico Distrófico.

Before the installation of the experiment, soil samples in 0 to $40 \mathrm{~cm}$ layer were collected in the area of projection of the tops of the plants of cv. "Paluma", for chemical characterization regarding fertility and physical attributes (Table 1). The projection area of the tops of the plants has been maintained and covered with an 8-cm-thick layer of grass Brachiaria decumbens. Chemical characteristics of the coverage before and at the end of the experiment were evaluated (Table 1).

\section{Experimental design}

The experimental design was a randomized block with a factorial arrangement of $2 \times 5$, with reference to the soil with and without $120 \mathrm{~g} \mathrm{plant}^{-1}$ year $^{-1}$ of Ca originating from calcium nitrate and potassium chloride at doses of $0,45,90$, 135 , and $180 \mathrm{~g} \mathrm{plant}^{-1} \mathrm{ano}^{-1}$ of $\mathrm{K}_{2} \mathrm{O}$, with three replications and three plants per parcel, in an orchard installed in July 2014, at age 13 months after transplanting (DAT). The Ca and the $\mathrm{K}$ doses were applied in the area of projection of the tops of the plants splitted three times all the same, one immediately after pruning of lateral branches, at the beginning of flowering, and 30 days after full flowering plants.

\section{Fertilizers in soil}

Fertilizers with $\mathrm{N}, \mathrm{P}$, and $\mathrm{K}$ were made separately from different sources, $\mathrm{N}$ with urea source, $\mathrm{P}$ monoammonium phosphate, and $\mathrm{K}$ with potassium chloride using the guava fertilization recommendation according to Natale et al. (2009). The nitrogen fertilization consisted of $160 \mathrm{~g} \mathrm{plant}^{-1}$ year $^{-1}$ of $\mathrm{N}$ from urea, deducted from the value added by the calcium nitrate and monoammonium phosphate, was provided in the levels of $30 \%$ after pruning of plants, $30 \%$ at the beginning of flowering, and $40 \%$ at 30 days after full flowering of Orchard.

The $K$ doses $\left(0,45,90,135\right.$, and 180 g plant $^{-1}$ year $^{-1}$ of $\left.\mathrm{K}_{2} \mathrm{O}\right)$, with the source of potassium chloride were parceled out in $30 \%, 30 \%$, and $40 \%$ applications along with nitrogen. The source of $\mathrm{P}$ was monoammonium phosphate-MAP at the dosage of $120 \mathrm{~g} \mathrm{plant}^{-1}$ year $^{-1}$ plant, in installments of $50 \%$, $25 \%$ and $25 \%$, applied simultaneously with nitrogen and $\mathrm{K}$. For zinc- and Mg-deficient soil (Table 1), $20 \mathrm{~g}$ of zinc sulfate and $30 \mathrm{~g}$ of magnesium sulfate were applied together with the first fertilization of NPK. Boron supplementation was done via foliar in three sprays with borax (11\% B), as suggested by Natale et al. (2009).

\section{Irrigation}

The irrigation of the plants during the dry season, from August 2015 to April 2016, was based on the potential evapotranspiration obtained from the evaporation of class " $A$ " tank installed in the experimental area. The cultivation coefficient (Kc) was used according to Teixeira et al. (2003) by the phenological phase: sprouting and vegetative growth (0.68); vegetative growth, flowering, and fall fruit physiology (0.76); fruit growth (0.71); and fruit maturation and harvest (0.62). The irrigation system was sprayed with a $92 \%$ application efficiency, using a $60 \mathrm{~L} \mathrm{~h}^{-1}$ flow rate emitter per plant installed at the time of wetting of the crown area of the plants, operating at a working pressure of $0.2 \mathrm{MPa}$.

\section{Analysis of soil fertility}

Soil fertility analysis was carried out at the end of the production in May 2016, evaluating the potential hydrogen $(\mathrm{pH})$, organic matter (OM), P with Mehlich-1, K, Ca (S), Mg, sodium $(\mathrm{Na})$, sum of bases $(\mathrm{SB})$, hydrogen plus aluminum $(\mathrm{H}$ $+\mathrm{Al}$ ), aluminum (Al), cation exchange capacity (CTC), and base saturation $(\mathrm{V})$, adapting the methodologies suggested by Embrapa (2011).

\section{Statistical analysis of the dato}

The results were submitted for analysis of variance, the means referring to the fertilization without and with Ca were compared by $\mathrm{F}$ test at levels of $1 \%$ and $5 \%$ of probability that is conclusive for two factors and the $\mathrm{K}$ doses by regression, using for the data processing software Statistical Analysis System (SAS ${ }^{\odot}$ /STAT 9.3, 2011).

\section{Conclusion}

The soil fertility was higher than that in the treatments with $\mathrm{K}$ fertilizer which has recommended doses between 90 and $135 \mathrm{~g} \mathrm{plant}^{-1} \mathrm{y}^{-1}$ without application of Ca in the soil.

\section{Acknowledgments}

The Coordination for the Improvement of Higher Education Personnel (CAPES) is acknowledged for granting the master's degree to the first author and the National Council for Scientific and Technological Development (CNPq) for the financial contribution to the work. We thank to the Postgraduate Program in Agronomy of the Federal University of Paraiba for the support in the development of the research. 


\section{References}

Amini S, Naeini SARM, Mashayekhi, K (2012). Effects of paper-mill sludge as a mulch versus topsoil incorporation on potassium uptake and the grain yield of rain-fed wheat in a high specific surface loess soil with illite dominance in clay fraction. Appl Environ Soil Sci. 12: 1-10.

Balaria A, Johnson CE, Groffman PM, Fisk MC (2015). Effects of calcium silicate treatment on the composition of forest floor organic matter in a northern hardwood forest stand. Biogeochemistry. 122 (2): 313-326.

Balic I, Ejsmentewicza T, Sanhuezaa D, Silvaa C, Peredoa T, Olmedoa P, Barrosa M, Verdonka JC, Paredesb R, Menesesa C, Prietoc H, Orellanaa A, Defilippic BG, Campos-Vargasa R (2014). Biochemical and physiological study of the firmness of table grape berries. Postharvest Biol Tec. 93: 15-23.

Cunha EQ, Stone LF, Ferreira EPB, Didonet AD, Moreira JAA (2012). Atributos físicos, químicos e biológicos de solo sob produção orgânica impactados por sistemas de cultivo. Rev Bras Eng Agríc Ambient. 16 (1): 56-63.

Edel KH, Marchadier E, Brownlee C, Kudla J, Hetherington AM (2017). The evolution of calcium-based signalling in plants. Curr Biol. 27 (13): 667-679.

Embrapa - Empresa Brasileira de Pesquisa Agropecuária (2013). Solos: Sistema Brasileiro de Classificação de Solos (3 ed), Rio de Janeiro, 2013.

Embrapa - Empresa Brasileira de Pesquisa Agropecuária (2011). Manual de Métodos de Análise do Solo (2 ed), Rio de Janeiro, 2011.

Feng S, Huang Y, Ge Y, Su Y, Xu X, Wang Y, He X (2016). Variations in the patterns of soil organic carbon mineralization and microbial communities in response to exogenous application of rice straw and calcium carbonate. Sci Total Environ. 571: 615-623.

Fida M, Khan S, Razzaq A, Nawaz I, Haq IU (2011). Fertility status of guava orchards in Kohat District of Pakistan. J Soil Sci Environ Manage. 3 (9): 260-268.

França SC, Oliveira AC, Farias GA, Cabral Junior LF, Silva VL (2017). Doses ses of nitrogen on the growth of rootstock goiabeira paluma yellow. Rev Sci Agrar. 18 (2): 54-65.

Jin SH, Huang JQ, Li XQ, Zheng BS, Wu JS, Wang ZJ, Liu GH, Chen $M$ (2011). Effects of potassium supply on limitations of photosynthesis by mesophyll diffusion conductance in Carya cathayensis. Tree Physiol. 31: 1142-1151.

Karley AJ, White JP (2009). Moving cationic minerals to edible tissues: potassium, magnesium, calcium. Curr Opin Plant Biol. 12 (3): 291-298.

Kumar TAK, Singha A, Shukla SK, Singh VK (2014). Assessing soil characteristics and guava orchard productivity as influenced by organic and inorganic substrates. J Anim Plant Sci. 24 (4): 1157-1165.

Lalitha M, Dhakshinamoorthy M (2015). Quantity-intensity characteristics of Potassium (K) in relation to potassium availability under different cropping system in alluvial soils. Afr J Agric Res. 10 (19): 2097-2103.
Marques DJ, Broetto F, Silva EC, Carvalho JG (2011). Dinâmica de cátions na raiz e folhas de berinjela cultivada sobre doses crescentes de potássio oriundas de duas fontes. Idesia. 29 (2): 69-77.

Moges A, Dagnachew M, Yimer F (2013). Land use effects on soil quality indicators: A case study of Abo-Wonsho Southern Ethiopia. Appl Environ Soil Sci. 1: 1-9.

Montes RM, Parent LÉ, Amorim DA, Rozane DE, Parent SÉ, Natale W, Modesto VC (2016a). Nitrogen and potassium fertilization in a guava orchard evaluated for five cycles: effects on the plant and on production. Rev Bras Ciênc Solo. 40: 1-12.

Montes RM, Parent LÉ, Amorim DA, Rozane DE, Parent SÉ, Natale W, Modesto VC (2016b). Nitrogen and potassium fertilization in a Guava Orchard Evaluated for Five Cycles: Soil Cationic Balance. Rev Bras Ciênc Solo. 40: 13-23.

Nascente AS, Cobucci T (2015). Soil phosphorus availability and dry bean yield as affected by the application of liquid calcium carbonate micron particles on the furrow. Afr J Agric Res. 10 (15): 1840-1851.

Natale W, Rozane DE, Parent LE, Parent SÉ (2012). Acidez do solo e calagem em pomares de frutíferas tropicais. Rev Bras Frutic. 34 (4): 1294-1306.

Natale W, Rozane DE, Souza HA, Amorim DA (2009). Cultura da goiaba: do plantio a comercialização (2 ad). Jaboticabal, 2009.

Natale W, Prado RM, Rozane DE, Romualdo LM (2007). Efeitos da calagem na fertilidade do solo e na nutrição e produtividade da goiabeira. Rev Bras Ciênc Solo. 31: 14751485.

Parent SE, Parent LE, Rozanne DE, Hernandes A, Natale W (2012). Nutrient balance as paradigm of soil and plant chemometrics. Soil Fertility. 4: 83-114.

Rozane DE, Torres MH, Souza HA, Natale W, Silva SHMG (2013). Application of a byproduct of guava processing in an Ultisol, in the presence and absence of mineral fertilization. Idesia, 31 (3): 89-96.

Embrapa - Empresa Brasileira de Pesquisa Agropecuária (2011). Manual de Métodos de Análise do Solo (2 ed), Rio de Janeiro, 2011.

SAS Institute Inc (2011). SAS/STAT 9.3 User's Guide. Cary, NC: SAS Institute Inc, North Carolina, 2011.

Silva RP, Peixoto JR, Junqueira NTV (2001). Influência de diversos substratos no desenvolvimento de mudas de maracujazeiro azedo (Passiflora edulis Sims f. flavicarpa Deg). Rev Bras Frutic. 23 (2): 1-5.

Souza HA, Rozane DE, Amorim DA, Modesto VC, Natale W (2014). Uso fertilizante do subproduto da agroindústria processadora de goiabas I - Atributos químicos do solo. Rev Bras Frutic. 36 (3): 713- 724.

Teixeira AHC, Souza CM, Borém A, Silva GF (2003). Estimativa do consumo hídrico da goiabeira, utilizando estações agrometeorológicas automática e convencional. Rev Bras Frutic. 25 (3): 457-460.

Wang X, Hua L, Ma Y (2012). A biotic ligand model predicting acute copper toxicity for barley (Hordeum vulgare): Influence of calcium, magnesium, sodium, potassium and pH. Chemosphere. 89 (1): 89-95. 